\section{Savoyard Highlands.}

Rambles in High Savgẹ By François Gos. Translated by Fran Kemp. Pp. 169. (London: Longm fos, treen and (9., Ltd., 1927.) 21s. net.

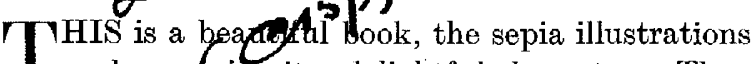
1 alone g(ving it a delightful character. They are reproductions of photographs, not by the author but by well-known Alpine photographers, including his celebrated father, Emile Gos. There are two prefaces by climbing friends, Mr. Geoffrey Winthrop Young and M. F. Regaut, president of the French Alpine Club, who was also the commander of the Alpine Corps, the famous 'Diables Bleus,' in the War. It may be that many would prefer a simple preface by the author himself, but that feeling is tempered by the pleasure which anything written by Mr. Young on his favourite subject must convey, and by the fact that the camaraderie of the War, in which the author served in the Alpine Corps under M. Regaut, has evoked highly interesting reminiscences of the great struggle from the latter in the course of his preface.

As its title implies, climbing in the chain of Mont Blanc is not the main subject of the book; it is more a description of walks and minor climbs in the foothills of that great chain, week-end rambles among them, from Geneva as base of operations. For anyone living at Geneva, or paying long visits to that delightful city, it is indeed ideal. For, as Mr. Young so admirably says, " We cannot think of Savoy as only glacial peaks and passes, nor as ... alps of summer flowers, nor yet only as romantic villages bright with festal costumes and musical voices. We think of it in single pictures which combine all three simultaneously."

How delightful many of these rambles can be! For they usually culminate in the arrival at the top of some eminence such as the Salève, the Môle, the Brezon, the Aravis, or the Col d'Anterne, from all or any of which we'see, growing in immensity and wonder and clearness of detail as we approach the eloser, the whole or greater part of the great chain of the most beautiful snow mountains in the world, culminating in the exquisite white dome of Mont Blane itself, the highest peak of the Furopean Alps, 15,782 feet above the sea. M. Gos writes in a very entertaining manner, and has given us a volume which it will ever be a pleasure to open. Moreover, the author has not suffered from his translator, who has maintained the author's own atmosphere quite remarkably well, and happily gives us the numerous poetic quotations in the original French.

$$
\text { A. E. H. TuTTON. }
$$

\section{Our Bookshelf.}

Economic Biology for Students of Social Science. By Dr. Philippa C. Esdaile. Part Harmful and Useful Animals. Pp. xv 175 . (London : University of London Pryperfit, 1927.) 7s.6d.
net.

THE author pathe to disarm criticism by stating in the preface that much ground was of necessity left untouched, and that the critic who cavils at this restriction must be even more ambitious than herself ! It is not so much the ground which has not been covered, but the whole point of view from which the book is written which calls for criticism. It deals briefly with the structure and life histories of those animal types which students of biology are required to study during their course in social and household science at King's College for Women. There are already a number of text-books of zoology which do the same sort of thing, and since this is a specialised course, which has special reference to social science and applied biology, it surely would have enhanced the value of this book if those applied aspects had been dealt with in detail, and the student referred to one of the general text-books for structure and anatomy.

Such important questions as the control of vencreal disease, treatmont of children for infection with Nomathelminthes and Platyhelminthes, and the ridding of houses of insect pests, ctc., are not describcd with any practical detail, and for the average student who does not know where to look for further information, and has little or no general scientific knowledge, the treatment of the subject is too scanty. One feels that a valuable opportunity has been lost of producing a book which might have opened the eyes of social workers, and incidentally of a large section of the general public, to the importance of applied biology. Much might have been done through a text-book for special courses, and by helping the students by a carefully chosen range of reading, but there is not even a bibliography appended.

H. E. B.

Theory of Machines: infextbook covering the Syllabuses of the B.Sos (E.), A.M.Inst.C.E., and A.M.I.Megh A Gaminations in this Subject. By Louis Tof A. I. J. Kersey. (Engineering Degrce Heries.) Pp. ix +408 . (London : Sir Isaac Pitman and Sons; Ltd., 1927.) 12s. 6d.net.

Although written primarily as a text-book for students reading for an engineering degree, this volume should prove equally useful to engineering draughtsmen and designers as a reference handbook spanning the gulf which is still sometimes thought to cxist between scientific principles and workshop practice. In the first four chapters the authors lay a sound theoretical foundation, and treat such matters as the laws of dynamics and simple harmonic motion with skill and clearness. Their experience as teachers has taught them where the beginner's difficulties generally lie. The rest of the book is concerned with the application of fundamental principles to actual mechanisms in everyday

No. 3034, VoL. 120] 